\title{
Failure to Identify the Defendant in Tort Law: Towards a Legislative Solution
}

\author{
Victor E. Schwartz $\uparrow$ \\ and \\ Liberty Mahshigian $\ddagger$
}

Prior to the late 1970's, an essential element of any plaintiff's product liability case was identification of the named defendant as the manufacturer or supplier of the allegedly defective product. ${ }^{1}$. But in the late 1970 's, nunnerous claims began to arise which imvolved a "generic" product and in which the plaintiffs alleged a defect im design or failure to warn common to all such products, such as asbestos or diethylstilbestrol ("DES"). Even where these plaintiffs have been able to prove that a manufacturer breached a duty of care in manufacturing the generic product under either a negligence or strict hability theory, that the defect in the generic product was the cause-in-fact and proximate cause of the plaintiff's harm, and that the plaintiff has suffered some provable mjuries, recovery has been uncertain. These cases are characterized by the existence of a generic product and a large number of potential defendants, and thus by an absence of evidence as to the identity of the manufacturer of the product that allegedly caused the injury. Moreover, im asbestos and DES cases, plaimtiffs are exposed to products many years before the injuries become manifest, which increases the plamtiffs' burden of producing evidence identifymg the manufacturer.

Courts have been wrestling with this problem of plaintiffs who are able to prove that their injuries were caused by some act that constituted

$\dagger$ Partner in the law firm of Crowell \& Moring, Washington, D.C.; A.B. 1962, Boston University; J.D. 1965, Columbia. Mr. Schwartz is the drafter of the Uniforn Product Liability Act, formerly Chairunan of the Working Task Force of the Federal Interagency Task Force on Product Liability and Chairınan of the Federal Interagency Council on Insurance. Mr. Schwartz is also coauthor of W. Prosser, J. Wade \& V. Schwartz, Cases and Materiais on TorTS (7th Ed. 1982) and author of V. SCHWARTZ, CoMparatiVE NEgligeNCE (2d Ed. 1985) and coauthor of V. SchwartZ, P. LeE, \& K. Kelly, Multidistrict Litigation (1985).

$\ddagger \quad$ Associate, Crowell \& Moring; B.A. 1980, Stanford University; J.D. 1983, University of California, Hastings College of Law. The views expressed in this Article are those solely of the authors and are not intended to reflect views or opinions of any chents of the firm of Crowell \& Moring.

1. See W. Keeton, D. Dobbs, R. Keeton \& D. Owen, Prosser and Keeton on the LAW OF TGRTS $\$ 103$, at 713-14 (5th ed. 1984) [hereinafter cited as Prosser \& KeEtoN]. 
a breach of duty to them but are not able to identify the actual wrongdoer. In a number of cases in which the plaintiff is able to prove all elements of his or her cause of action except the identity of the wrongdoer, courts have fashioned several theories to hurdle the plaintiff over the barrier posed by the identification requirement. All of these theories deviate from traditional and fundamental principles of tort law. Their developinent is motivated by the courts' pohicy judgment that as between an innocent plaimtiff and defendants who are allegedly guilty of some wrongful conduct, the plamtiff should prevail-even if the alleged (not necessarily established) conduct in question did not cause the plaintiff's injury.

Thus, in a number of recent cases plamtiffs have brought actions against an entire group or a substantial number of manufacturers that made such a generic product, seeking recovery against the joined manufacturers under several theories of liability. In a few cases, courts have modified traditional requirements of alternative liability or concerted action hability in order to afford recovery for plaintiffs, expanding these theories beyond the point at which liability can be justified. In other cases, courts have developed completely new theories, imposing liability on inany or all ineinbers of an mdustry while apportioning damages accordimg to any of a variety of factors. These latter theories are riddled with many practical problems, often raising confusing or complicated issues that render htigation slow, complex, and costly for all parties involved. Furthermore, imposition of hability without regard to individualized fault is often unfair to certain defendants, and inconsistent with a basic underlying notion of the tort system: that only one who is responsible for causing particular and identifiable harm should be held liable for civil dainages. ${ }^{2}$

The DES nonidentification cases present an unresolved dilemma. On the one hand, courts can deny liability in all of these cases. Most trial courts have done this and have thus reniamed in step with the existing parameters of tort law. But denying all recovery to plaintiffs offends some courts' sense of justice. On the other hand, courts can create a novel judicial theory in order to impose liability. While this might satisfy some courts' sense of justice, it leaves in its wake extraordinary legal costs, delay, injustice, and the inıposition of tort law liability on a party who is, in fact, not responsible for plamtiff's harm.

This Article will begm by examining the various ways that courts have struggled to deal with the identification problen $\mathrm{m}$ cases involving a generic drug, DES. It will show that the tort litigation systen is not able to resolve the identification problen 1 and thus that the problem can only

2. J. Fleming, The Law of TORTS 179-81 (6th ed. 1983); Prosser \& KeEton, supra note 1 , at $41,263-68$. 
be resolved satisfactorily by a legislative solution. This Article will then provide, on the basis of the problems raised by these common law solutions, a framework for a legislative solution to the problem.

I

\section{The Background: The Development and Marketing OF DES}

In order to appreciate fully the identification problem as it applies to DES, it is essential to understand how the drug was developed and marketed. Let us begin with some basic scientific facts. Natural estrogens, the female sex hormones present in varying amounts in the body of every woman, were first isolated outside the human body in 1929. Pliysicians and scientists soon discovered that the administration of controlled doses of natural estrogens could alleviate medical problems associated with estrogen deficiencies. Natural estrogens, however, still very expensive to isolate, and were difficult and painful to administer by mjection.

In 1937, two Britisl1 scientists, Drs. E.C. Dodds and Leon Golburg, synthesized a compound that has most of the characteristics of estrogen. The synthetic estrogen, stilbestrol, also called diethylstilbestrol and more commouly referred to as DES, could be produced at a fraction of the cost of isolating natural estrogens and was effective when administered orally. Dr. Dodds did not apply for a patent, leaving the product available for marketing by all. $^{3}$

Before DES could be marketed in the United States, approval of the Food and Drug Administration ("FDA") was required. ${ }^{4}$ Federal law required that each company wishing to market DES submit a New Drug Application ("NDA"), and that this application include a description of the chemical composition of the drug, climcal data establishing its safety and efficacy, information regarding the methods for inanufacturing, processing, and packing the drug, and the format of proposed labeling. ${ }^{5}$

By the end of 1940, ten pharmaceutical companies had filed NDA's seeking approval to market DES in up to one milligran doses to treat various conditions, including menopausal symptoms, senile vaginitis, and gonorrlieal vaginitis. None of these proposed uses involved inedical conditions relating to pregnancy. A large amount of clinical data was independently collected and submitted to the FDA ${ }^{6}$ On Deceinber 20, 1940, the FDA convened a meetimg with the drug coinpanies, at which it formally requested the companies to withdraw their NDA's and submit

3. Ferrigno v. Eli Lilly and Co., 175 N.J. Super. 551, 562, 420 A.2d 1305, 1310 (1980).

4. See 21 U.S.C. $\S 355$ (1982).

5. See 21 U.S.C. $\S 355(b)$ (1982).

6. Ryan v. Eli Lilly \& Co., 514 F. Supp. 1004, 1009 (D.S.C. 1981). 
their clinical studies jointly in a "master file."7 The FDA also requested the drug coinpanies to use the same United States Pharmacopeia (U.S.P.) standard to ensure that the active ingredient in all DES products was the same, to develop uniform labeling regarding usage and dosage of the drug, and to include a "permission clause" in their NDA's authorizing the FDA to use the inaterials gatliered by eacli firm in considering any otlier NDA's that miglit be filed. ${ }^{8}$ In response, representatives of firms that had filed NDA's formed a sinall coinmittee to compile the studies and clinical data into the inaster file that was submitted to the FDA. The coinpanies then filed individual NDA's and, in September of 1941, the FDA approved the marketing of DES for use in the treatment of menopausal symptoins, senile vagimitis, gonorrleal vaginitis, and suppression of lactation. The sinall committee disbanded in October 1941.9

Throughout the late 1930's and the 1940's, independent physicians conducted research on other possible uses for DES, including the treatment of pregnancy problems. ${ }^{10}$ In 1944, the FDA approved the use of DES for treatment of prostate cancer im men. ${ }^{11}$ In 1947 , following published reports of successful treatinent, several coinpanies filed new or suppleinental NDA's for the use of DES as a miscarriage preventative. Althougl these NDA's did not refer to the master file of clinical data that had been submitted witl the 1941 NDA's, it was the FDA's policy to consider all of the inaterial that it had in support of the original NDA's. By 1952, the FDA had decided that DES was no longer a "new drug." This meant that coinpamies wishmg to market DES did not have to file NDA's. ${ }^{12}$

In 1971, Dr. Arthur Herbst and two colleagues published a paper suggesting a statistical relationship between fetal exposure to DES and a specific form of cancer, called clear cell adenocarcinoma, in some of the daughters of woinen who had taken the drug during pregnancy. ${ }^{13}$ In the period of time between the FDA approval of DES and the publication of this article in 1971, almost 300 drug companies had marketed DES in

7. Martin v. Abbott Laboratories, 689 P.2d 368, 374 (Wash. 1984).

8. Id. at 374.

9. Id.

10. Ryan v. Eli Lilly \& Co., 514 F. Supp. 1004, 1009-10 (D.S.C. 1981); Payton v. Abbott Labs, 512 F. Supp. 1031, 1034 (D. Mass. 1981).

11. Huggins, A Summary of Endocrin Effects in Advanced Prostatic Cancer, 7 CoNN. ST. MED. J. 90 (1943); Huggins, Scott \& Hodges, The Effects of Fever, of Desoxycorticosterone and of Estrogen on Clinical Patients with Metastatic Carcinoma of the Prostate, 46 J. URoLogy 997 (1941).

12. Payton v. Abbott Labs, 512 F. Supp. 1031, 1034 (D. Mass. 1981).

13. Herbst, Ulfelder \& Poskanzer, Adenocarcinoma of the Vagina: Association of Maternal Stilbestrol Therapy with Tumor Appearance in Young Women, 284 NEw ENG. J. MED. 878 (1971). For an excellent overview of the medical literature surrounding the DES problem and a useful collection of citations, see Note, Proof of Causation in Multiparty Drug Litigation, 56 TEx. L. REv. 125, 126 n.11 1977). 
dosages suitable for use in the treatment of certain pregnancy problems. ${ }^{14}$ After much further study and discussion, the FDA required drug coinpanies in their labeling to recommend against DES use in the prevention of iniscarriages. DES was never banned by the FDA and is still used today for treatment of problems unrelated to pregnancy, such as cancer of the prostate, certain forms of breast cancer, and menopausal syinptoms. ${ }^{15}$

Woinen who were exposed to DES taken by their inothers during pregnancy have sought to recover damages from DES inanufacturers. Some of these woinen have adenosis, which is a benign condition characterized by the presence of glandular tissue in the vagina where it does not usually appear. Adenosis has not been shown to be a precancerous condition and it seeins to regress and disappear over tine. It is a condition that also exists in woinen who were not exposed to DES. ${ }^{16}$ Because the condition is benign and usually disappears by the time the woinen reach their late twenties, no inedical or surgical therapy is necessary and actual physical harm is ininimal. For that reason, plaintiffs have seldom pursued adenosis dainage claims in court.

Other women who were exposed to DES developed vaginal or cervical cancer and have brought suit. One important study has reported a statistical association between clear cell adenocarcinoma and DES. ${ }^{17}$ Many of these woinen, however, are unable to identify the manufacturer of the DES taken by their inother, in part because of the passage of tine resulting in the absence of records, and in part because DES usually was prescribed by a generic and not a brand naine. As a result of their inability to identify the inanufacturers of the DES taken by their mothers, some woinen have brought suit against several DES inanufacturers. Most courts, recognizing and following traditional principles of tort law, have denied recovery to plaintiffs unable to satisfy the identification requirement. A few courts have permitted these actions to proceed by applying various traditional theories of joint liability, but as discussed below, traditional tort theories of joint liability will not rationally extend to the circumstances of DES cases. Because of this, some courts have modified traditional jomt liability theories and have developed new theories in order to provide causes of action for DES plaintiffs.

14. Martin v. Abbott Laboratories, 689 P.2d 368, 374 (Wash. 1984).

15. Id. at 373, 374; Ferrigno v. Eli Lilly and Co., 175 N.J. Super. 551, 565, 420 A.2d 1305, 1312 (1980).

16. Antonioli, Burke \& Friedman, Natural History of Diethylstilbestrol-Associated Genital Tract Lesions: Cervical Ectopy and Cervicovaginal Hood, 137 AM. J. OBSTETrics \& GYNECOLOGY 847-53 (1980); Burke, Antonioli \& Friedman, Evolution of Diethylstilbestrol-Associated Genital Tract Lesions, 57 OBSTETRICS \& GYNECOLOGY 79-84 (1981).

17. Herbst, Ulfelder \& Poskanzer, supra note 13. 
II

\section{THE COMMON LAW THEORIES OF RECOVERY: INABILITY \\ OF THE TORT Litigation SYSTEM TO RESOLVE THE DES IDENTIFICATION PROBLEM}

\section{A. Summers v. Tice Alternative Liability}

The first modern theory of alternative hability was judicially created in Summers v. Tice. ${ }^{18}$ In that case, the California Supreme Court ruled that where two defendants had both acted negligently toward the plaintiff, each could be hable for the harm caused, although only one of the defendants could have been the cause-in-fact of the plaintiff's injury. The defendants in Summers neghigently fired, at the same time, at a quail in the plamtiff's direction. The plaintiff was struck in the eye and face by a shot from one of the guns. Unable to prove which one of the two defendants had fired the imjury-causing shot, the plaintiff filed suit against both.

The court recognized that while both defendants had acted negligently, only one of the two defendants had actually caused the plaintiff's harm. The court held that each defendant wonld be jointly and severally hable for the harm unless he could prove that he was not the person who fired the injury-causing shot. The court reasoned that it was preferable that the two wrongdoers, both of whom had acted negligently toward the plaintiff and had better access to the relevant evidence, should bear the burden of absolving themselves rather than leaving the innocent plaintiff remediless. ${ }^{19}$

The Summers alternative liability theory soon gained acceptance in a few courts and was adopted by the authors of the Second Restatement of Torts. ${ }^{20}$ Today, the prevailing judicial view is that the Summers alternative hability theory should apply if (1) all the potential wrongdoers are jomed as defendants, (2) all of the defendants acted tortiously, and (3) the defendants are in a better position to prove the identity of the actual wrongdoer. ${ }^{21}$ The plaintiff is not required to show an express agreement or tacit understanding among the defendants; thus, unlike the concerted action theory discussed below, the Summers alternative liability theory can be used to impose hability on defendants who acted independently.

18. 33 Cal. 2d 80, 199 P.2d 1 (1948).

19. $33 \mathrm{Cal} .2 \mathrm{~d}$ at 86,199 P.2d at 4 .

20. See, Restatement (SECOND) of TORTS § 433B(3) (1964); see also F. HARPer \& F. JAMES, THE LAW OF TORTS, $\S 20.2$, at 1115-16 (1956). It should be noted that Summers v. Tice alternate hability differs from alternate liability in the strict sense in that the latter usually involves a situation where several parties were in a position to cause plaintiff's harm, but there is no proof that all defendants acted tortiously. See Prosser \& KeEton, supra note 1, §41, at 270-71; see also RESTATEMENT (SECOND) OF TORTS, § 433B(3) coiminent g (1964).

21. Restatement (SECOND) OF ToRTS $\S 433 B$ (1964); see also Starling v. Seaboard Coast Line R.R., 533 F. Supp. 183, 188 (S.D. Ga. 1982); Sheffield v. El Lilly \& Co., 144 Cal. App. 3d 583, 595, 192 Cal. Rptr. 870,877 (1983). 
Courts have refused to apply the theory in DES cases, however, for several reasons. Most courts have refused to apply alternative liability because the plaintiffs as a practical matter are unable to bring all possible tortfeasors before the court. Over 300 drug coinpanies niarketed DES for use in connection with pregnancy problenis. It would be very difficult for a plaintiff to determine which of the 300 companies nay have marketed the DES taken by her mother, to locate these companies, to obtain jurisdiction over them, and to serve process on them.

Second, the alternative hability theory presupposes that all parties who could have been responsible for plaintiff's harm have been joined as defendants. ${ }^{22}$ Unless plaintiffs join every inanufacturer of DES that was sold in the area during the time of exposure to the drug, the responsible manufacturer may not be one of the defendants. Where substantially less than all possible tortfeasors have been joined as defendants, it would be unfair to shift the burden of proving identification to the defendants, since it is probable that none of the defendants before the court the caused plaintiff's harm. Liability in such a case would shift the burden of proof to a group of defendants who may not have been the cause in fact of the injury.

Third, courts have pointed out that the Summers theory is inappropriate for DES cases because the DES manufacturers are not in a better position to offer evidence to establisl who manufactured the drug ingested by plaintiff's motlier. ${ }^{23}$ In Summers-like fact situations, the defendants are in a better position to prove which of them caused the injury, thus justifying a shift in the burden of proof. Summers and Tice were the best persons to testify as to tlie aim of their gnns and the destination of their shots. In contrast, the DES manufacturers are not in control of all evidence relevant to the identification of the drug ingested by a plaintiff's motlier-tlre plrarmacy where it was purcliased, the size and shape of the pills, the dates of purcliase, and so on. Thus, the primary justification for slifting the burden of proving identification in Summers is not present in DES cases. To shift tlie burden of proving identification to DES inanufacturers is not only unfair to the DES manufacturers but is also inefficient, because it shifts the burden of proof to a party not in control of the relevant evidence.

The Summers theory is inappropriate for application in DES cases for a fourtli reason. A justification for imposing liability on both Sum-

22. See Restatement (SeCOND) TORTS, $\S 433 \mathrm{~B}(3)$ \& comment h (1964).

23. See, eg., Morton v. Abbott Laboratories, 538 F. Supp. 593 (M.D. Fla. 1982); Ryan v. Eli Lilly \& Co., 514 F. Supp. 1004, 1016 (D.S.C. 1981); Sindell v. Abbott Laboratories, 26 Cal. 3d 588, 163 Cal. Rptr. 132, 607 P.2d 924, cert. denied, 449 U.S. 912 (1980); Sinith v. Eli Lilly \& Co., No. 80 L. 20473 (Cir. Ct. Cook County Ill. October 10, 1984); Zafft v. Eli Lilly \& Co., 676 S.W.2d 241 (Mo. 1984); Collins v. Eli Lilly Co., 116 Wis. 2d 166, 183, 342 N.W.2d 37, 46 (1984). 
mers and Tice, as well as for shifting the burden of proof, was that both defendants had acted neghigently toward the plaintiff, although the negligence of only one of them was the cause-in-fact of the injury. Yet in almost every DES case decided to date, the plaintiff has failed to show that the manufacturers of DES acted negligently toward her, though they may have acted neghigently toward DES users. Absent proof of any negligent conduct, the fact that a company produced a drug, but not the particular drug that allegedly caused the plaintiff's injury, by no means establishes that the company breached a duty of care toward the plaintiff.

Notwitlistanding these difficulties, the Michigan Supreme Court has recently applied a variation of the Summers theory of alternative liability to a DES case. In Abel v. Eli Lilly \& Co. ${ }^{24}$ the Michigan Supreme Court ruled that the theories of alternative liability and concert of action may be apphed in suits brought by DES daughters who cannot identify which specific company made the drugs that their mothers took when pregnant. The court modified the elements of the traditional theory of alternative liability, settimg out three requirements that plaintiffs must meet in order to recover under this theory. To shift the burden of proof to defendants on the issue of causation in fact under the modified theory, a plaintiff must sliow that (1) all the defendants acted tortiously, (2) she has been harmed by the conduct of one of the defendants, and (3) she is unable, through no fault of her own, to identify which defendant caused her injury. ${ }^{25}$ As a prerequisite to recovery, the plaintiff is also required to show that she has made a genuine attempt to locate and identify the manufacturer responsible for her individual injury. The genuineness of this attempt will be determined by the standard of "due diligence".26

In order to support the second requirement, the plaintiff must bring before the court all parties who promoted DES in Michigan at the time her mother took the drug. ${ }^{27} \mathrm{~A}$ plaintiff must prove that all the defendants manufactured one or more of the three chemically related drugs mvolved (DES, dienestrol, or diethylstilbestrol dipropionate), that her mother imgested one of these drugs, that the drug her mother ingested

24. 418 Mich. 311,343 N.W.2d 164, cert. denied, 105 S. Ct. 123 (1984).

25. Id. at $331-32,343$ N.W.2d at 173.

26. Id. Some of the plaintiffs in this case alleged that they were unable to identify the manufacturer of the product that harmed them because of the absence of pharmacy records and the defendants' use of a generic marketing scheme. Michigan law requires pharmacists to maintain prescription drug records for only five years. Id. at 321,343 N.W.2d at 168 . The court held that the pleadings were sufficient to withstand a motion to dismiss. Id. at $340-41,343$ N.W.2d at 176-77. Although the Michigan court called the motion a "motion for summary judgment," it was a motion based solely on the pleadings and not on the facts and accordingly, actually was a motion to dismiss. Id. Heremafter, it will be referred to as a motion to dismiss. The remaining plaintifis were permitted to offer proof of the identity of the manufacturers liable; if unable to identify the manufacturers, they conld resort to the alternative hability theory.

27. Id. at 331,343 N.W.2d at 173. 
was manufactured or distributed in Michigan, and that the three drugs are essentially identical in their allegedly injury-producing results. If the defendants are unable to exculpate themselves, they will be jointly and severally liable for plaintiff's damages. ${ }^{28}$

By requiring the plamtiff to bring forth all possible defendants and by requiring that all of the defendants to have breached a duty toward some potential plaintiff, the Michigan court solved some of the problems arising from the application of Summers to DES cases. Specifically, all defendants have allegedly breached a duty of care and are all present before the court, thus justifying to a limited extent a shifting of the burden of proof. But the Michigan court did not resolve the problem in administration caused by the requirement that the plaintiff bring all defendants before the court. complex And the Michigan court failed to realize that smce defendants are not in a better position than plaintiffs to come forward with identification information, the full policy justification of Summers is inissing here, raising the spectre of an arguably unfair shift in the burden of proof that will $\mathrm{m}$ practice operate as an unfair finding of alternative liability. Finally, the adoption of the Summers doctrine in a context where no breach of a duty of care to the plaintiff by a defendant before the court has been established ignores, to a greater extent than in Summers, the tradtional tort law requirement of cause-in-fact. In sum, the application of Summers to DES cases, even if qualified as in $A b e l$, solves the DES problem by ignoring probleins of proof for plaintiffs and problems of unfairness toward defendants.

\section{B. Concert of Action}

Courts have also developed the concert of action theory to mitigate the identification problein. This theory imposes joint and several liability on all persons who acted in concert or pursuant to a common scheme or plan to commit a tortious act, even though fewer than all of those persons actually caused the harm. ${ }^{29}$ The paradigm concert of action case is a drag race in which all who participate in the race are deemed responsible should one of thein cause harm to a bystander. ${ }^{30}$ The defendants who acted in concert were "joint tortfeasors" and "the act of one is the act of all."31 The rationale for imposing hability is that while the party on whom habihty is inposed may not have actually caused the injury, his or her wrongful conduct actively encouraged the one who did.

28. Id. at 334,343 N.W.2d at 174 .

29. See Prosser \& KeEton, supra note $1, \S 46$, at 322-24.

30. See, eg., Bierczyniski v. Rogers, 239 A.2d 218 (Del. 1968); RESTATEMENT (SECOND) of TORTS, $\S 876$ (1977). Such "concerted" wrongdoers were considered "joint tortfeasors" even by the early common law. Prosser \& KeETon, supra note 1, § 52, at 346.

31. Prosser \& KeEton, supra note $1, \S 52$, at 346. 
Unlike the theory of alternative liability, concert of action does not require the presence of the injury-inflicting party before the court. ${ }^{32}$ Thus, a plaintiff's inability to identify the defendant which caused his or her injury does not preclude recovery froin all defendants. Sinilarly, a defendant joint tortfeasor who is able to prove that he or she did not cause the plaintiff's harm is not able to avoid liability. As applied to DES cases, and unlike the alternative liability theory, the concert of action theory does not permit a defendant to escape liability by showing that it did not manufacture the type of DES taken by the plaintiff's nother or that it did not market DES at the time or in the area in which the plaintiff's mother purchased the drug. ${ }^{33}$

At least one court has imposed liability on DES manufacturers under a revised version of the concert of action theory. In Bichler v. Eli Lilly \& Co. ${ }^{34}$ the plaintiffs argued to a New York trial court that the "parallel and imitative" conduct of the DES manufacturers should be enough to sliow concerted action. The plaintiff inade no showing that the defendant actively encouraged others into negligent conduct. The trial court instructed the jury that the "inplied or tacit agreement or understanding" eleinent of concerted action could be evidenced by the "conscious parallel" conduct of the drug comparies. ${ }^{35}$ The court further stated that the concerted action could also be defined as "acting independently of each other in committing the same wrongful act, but although acting independently, their acts have the effect of substantially encouraging or assisting the wrongful conduct of the other, which, in this case, was the alleged failure to adequately test." 36

The trial court entered judgment in favor of the plaintiff, and the defendant appealed. The Appellate Division affirmed, ${ }^{37}$ and Eli Lilly \& Company again appealed, seeking reversal on two grounds: the trial court's instructions on concerted action liability were erroneous, and the evidence before the jury was legally insufficient to support a verdict in the plaintiff's favor on the issue of concerted action. The New York Court of Appeals found that it could not review the instruction because the defendant had failed to preserve the challenge for review by appropriate objections. ${ }^{38}$ Thus, although it affirmed the Appellate Division, the Court of Appeals did not decide whether evidence of "conscious parallelisin" ainong the drug inanufacturers is sufficient to establish concert of

32. Id., § 47 , at 327 .

33. See Abel v. Eli Lilly \& Co., 418 Mich. 311, 338, 343 N.W.2d 164, 176.

34. 79 A.D.2d 317, 436 N.Y.S.2d 625 (1981), affd, 55 N.Y.2d 571, 436 N.E.2d 182, 450 N.Y.S.2d 776 (1982).

35. Bichler, 79 A.D.2d at 326,436 N.Y.S. $2 d$ at 631.

36. Id.

37. Id. at 336,436 N.Y.S. $2 d$ at $636-37$.

38. 55 N.Y.2d 571, 583, 436 N.E.2d 182, 187, 450 N.Y.S.2d 776, 781 (1982). 
action. Therefore, it is not certain what type of conduct is necessary to constitute concert of action in New York.

Other courts have rejected the "conscious parallelisin" approach to concert of action hability. The Wisconsin Supreme Court held that

[the plaintiff's allegations that the] "defendants failed to adequately test [DES] or to give sufficient warning of its dangers and that they relied upon the tests performed by one another and to the advantage of each others' promotional and marketing techniques" . . . do not support the theory that the defendants tacitly agreed to produce and market DES without adequately testing the drug or warning of its potential dangers. ${ }^{39}$

The court concluded that "[a]1though there was a substantial amount of parallel action by the defendants in producing and marketing DES for use in pregnancy," the extent of parallel action did not "rise to the level of 'actimg in concert." "40 Similarly, the California Supreme Court determined that concerted action could not be established by evidence of "parallel or imitative conduct" ${ }^{41}$ and thus refused to apply concert of action liability to the drug compames' conduct in "rel[ymg] upon each others' testing and promotion methods." The court reasoned that such conduct was a "common practice in the industry"42 and that applying a concert of action theory to those circumstances "would expand the doctrine far beyond its intended scope." "[V]irtually any manufacturer [could be held] liable for the defective products of an entire industry, even if it could be demonstrated that the product which caused the injury was not made by the defendant." 43 Courts in New Jersey, South Carolima, Florida, and Missouri have also rejected the New York Appellate Division's "conscious parallelism" basis for concert of action liability.

In Abel v. Eli Lilly and Co. ${ }^{45}$ the Michigan Suprene Court permitted the DES plaintiffs to proceed on a concert of action theory as well as an alternative liability theory. The court stated that the defendant manufacturers would be jointly and severally liable for the plaintiffs' damages if the plaintiffs could establish that all defendants acted tortiously pursuant to a "common design." 46 In order to withstand a motion to dismiss,

39. Collins v. Eli Lilly Co., 116 Wis.2d 166, 185, 342 N.W.2d 37, 46 (quoting Sindell v. Abbott Laboratories, 26 Cal. 3d 588, 605, 163 Cal. Rptr. 132, 140, 607 P.2d 924, 932, cert. denied, 449 U.S. $912(1980))$.

40. Id.

41. Sindell v. Abbott Laboratories, 26 Cal. 3d 588, 605, 163 Cal. Rptr. 133, 141, 607 P.2d 924, 933, cert. denied, 449 U.S. 912 (1980).

42. Id.

43. Id.

44. See Morton v. Abbott Laboratories, 538 F. Supp. 593 (M.D. Fla. 1982); Zafft v. Eli Lilly \& Co., 676 S.W.2d 241 (Mo. 1984); Ferrigno v. Eli Lilly \& Co., 175 N.J. Super. 551, 420 A.2d 1305 (1980); Lyons v. Premo Pharmaceutical Laboratories, Inc., 170 N.J. Super, 183, 406 A.2d 185, certification denied, 82 N.J. 267, 412 A.2d 744 (App. Div. 1979).

45. 418 Mich. 311, 343 N.W.2d 164 (1984).

46. Id. at 338,343 N.W.2d at 176 . 
a plaintiff had only to allege that the defendants were "jointly engaged in tortious activity as a result of which the plaintiff was harmed."47 The plaintiffs' allegations that the defendants "acted together in negligently manufacturing and promoting drugs which were ineffective and dangerous, were inadequately tested, and were distributed without sufficient warnimgs," thus could withstand a motion to dismiss. ${ }^{48}$ The court noted that the concert of action theory, unlike alternative liability, does not require that a plamtiff be unable to identify the specific defendant who caused his or her injury. The fact that some of the plaintiffs in this case had alleged that a specific DES manufacturer caused their injuries would not preclude them from recovering from all of the defendants under a concert of action theory. ${ }^{49}$

To summarize, all states except New York and Michigan have rejected the concert of action theory in DES cases. This may be due to the conceptual inapplicability of the theory in DES cases. In paradigm cases of acting in concert, such as the acting together to hold a drag race, the concerted activity was itself tortious. As pointed out by one district court, none of the drug companies' concerted activities-the filing of wholly separate applications to the FDA for permission to inarket DES, the formation of a small coinmittee, the resubmission of their applications to a master file-constitute tortious action. ${ }^{50}$ As pointed out by another court, the concerted action theory only applies to action such as express or tacit agreement, or a counmon plan to inadequately test DES or to fail to warn the public of the drug's known dangers. ${ }^{51}$ Plaintiffs can rarely prove such conduct, and courts have been justifiably unwilling to assume that such conduct took place, and have generally looked elsewhere to solve the DES identification problein.

\section{Enterprise Liability}

The "enterprise liability" theory, first recognized by a federal district court in New York, presents a third possible basis for recovery in DES cases. In Hall v. E.I Du Pont De Nemours \& Co., ${ }^{52}$ thirteen children were injured in twelve separate blasting cap incidents over a period of four years. The plaintiffs were not able to identify the specific manu-

47. Id.; see also supra note 26.

48. Id.

49. Id.

50. Morton v. Abbott Laboratories, 538 F. Supp. 593, 596-97 (M.D. Fla. 1982); see also Lyons v. Premo Pharmaceutical Labs, 170 N.J. Super. 183, 406 A.2d 185 (App. Div. 1979) (no concert of action because drug companies' act of seeking approval for DES was not tortious, nor shown to have encouraged a tortious act).

51. Ryan v. Eli Lilly \& Co., 514 F. Supp. 1004, 1016 (D.S.C. 1981) (citing Birnbaum, DES Concert-of-Action Theory: New Cases Bring New Confusion, Nat'l L.J., May 4, 1981, at 31, col. 1.

52. 345 F. Supp. 353 (E.D.N.Y. 1972). 
facturers of the caps that had injured them. They sought damages from six blasting cap manufacturers, that made up virtually the entire American industry, and from the manufacturers' trade association.

The court imposed liability on the entire industry, even though only one inember of that industry had actually caused the harm, because all members jointly controlled the risk either by an express agreement or by parallel behavior in delegating safety functions and adhering to insufficient safety standards. ${ }^{53}$ Under this industry-wide hability theory, the existence of industry-wide standards or practices inay support a finding of joint control of risk and shift the burden of proving identification to the defendants. ${ }^{54}$

Unike the concert of action theory, enterprise hability does not require the plaintiff to prove the existence of an exphicit agreement to commit a tort. Furthermore, the plaintiff is not required to demonstrate that the industry is rigidly controlled through trade associations or that the purpose of this common control is some particularly reprehensible breach of duty. ${ }^{55}$ The plaintiff begins by showing that her injury was caused by a product made by one of the nained defendants and that the particular manufacturer is unknown. ${ }^{56}$ Second, to shift the burden of proof to the defendants, the plaintiff must "demonstrate defendants' joint awareness of the risks at issue im [the] case and their joint capacity to reduce or affect those risks." 57 The court stated that the factors relevant to the existence of joint control of risk include

the size and composition of the trade association's membership, its announced and actual objectives in the field of safety, its imternal procedures of decision-making on this issue, the nature of its information-gathering system with regard to accidents, the safety program and its implementation by the association and nember manufacturers, and any other activities by the association and its members (such as legislative lobbying) with regard to safety during the time period in question..$^{58}$

The application of this theory is very limited. In fact, it has never been adopted by any other court and was not even apphed by the trial courts in any other blasting cap case. The theory had been rejected by courts in California, South Carohina, and Missouri because of the requirement of a centratized industry. ${ }^{59}$ Similarly, in Collins v. Eli Lilly

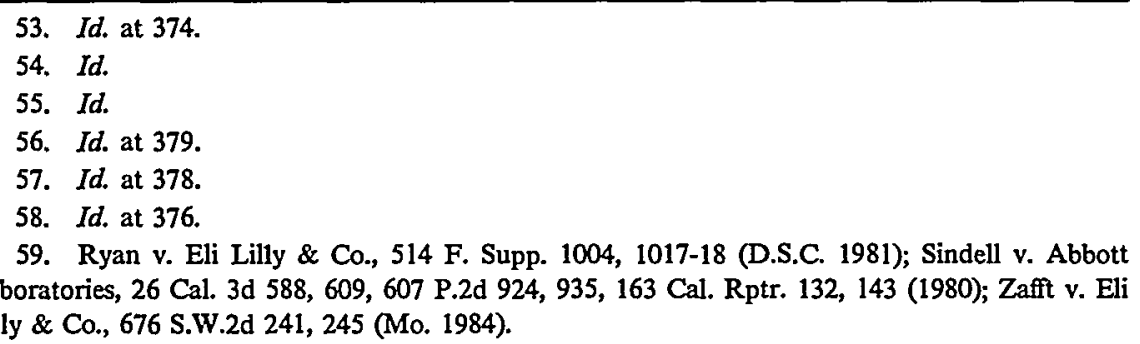


$\&$ Co. ${ }^{60}$ the Wisconsin Supreme Court held that the enterprise liability theory is inappropriate in DES cases involving hundreds of potential defendant drug companies. The court pointed out that "the assumption that the defendants jointly controlled the risk of injury is necessarily weak given the fact that so many drug coinpanies entered and left the DES marketplace from 1947 to 1971," and "[i]t is less clear in DES cases than in Hall that the defendant drug compames were each violating a standard of safety, whether federally imposed or industry imposed, in producing and inarketing DES for use in pregnancy."61 The theory also has been expressly rejected in DES cases in Florida, Michigan, New Jersey, and Washington. ${ }^{62}$

This widespread rejection of the enterprise liability theory is hardly surprising. As the Hall court exphicitly recognized, it is "manifestly unreasonable" to apply the theory to a "decentralized industry composed of thousands of small producers."63 For as commentators have argued, the enterprise hability theory should not apply in cases involving a large number of defendants because as the number of manufacturers increases, jomt control and awareness of the risks at issue, and joint capacity to reduce those risks, become inore difficult to imply as a predicate to liability. ${ }^{64}$ Additionally, the drug industry is required to comply with the standards and conditions set by the FDA. ${ }^{65}$ Courts rejecting the enterprise theory have recognized that in industries where standards are mandated by the government, the manufacturer has no choice but to comply, and compliance thus should not be a basis for liability. ${ }^{66}$ To apply the enterprise liability theory absent a finding of industry-wide control of standards and conditions would, of course, provide compensation to DES plaintiffs, but would again raise serious problems of fairness to defendants.

\section{Market-Share Theory of Liability}

In Sindell v. Abbott Laboratories, ${ }^{67}$ the California Supreme Court

60. 116 Wis. 2 d 166, 342 N.W.2d 37 (1984).

61. Id. at $186-87,342$ N.W.2d at 47 (footnote omitted).

62. Morton v. Abbott Laboratories, 538 F. Supp. 593, 598 (M.D. Fla. 1982); Abel v. Eli Lilly \& Co., 418 Mich. 311, 337, 343 N.W.2d 164, 175-76 (1984); Namm v. Charles E. Frosst \& Co., 178 N.J. Super. 19, 35, 427 A.2d 1121, 1129 (App. Div. 1981); Martin v. Abbott Laboratories, 689 P.2d 368,380 (1984).

63. Hall v. E.I. Du Pont De Nemours \& Co., 345 F. Supp. 353, 378 (E.D.N.Y. 1972).

64. See Comment, Overcoming the Identification Burden in DES Litigation: The Market Share Liability Theory, 65 MARQ. L. REV. 609, 621 (1982).

65. Id.

66. See Ryan v. Eli Lilly \& Co., 514 F. Supp. 1004, 1018 (D.S.C. 1981); Sindell v. Abbott Laboratories, 26 Cal. 3d 588, 609-10, 607 P.2d 924, 935, 163 Cal. Rptr. 132, 143, cert. denied, 449 U.S. 912 (1980).

67. 26 Cal. 3d 588, 607 P.2d 924, 163 Cal. Rptr. 132 (1980). 
adopted a new basis upon which defendants may be liable even though the plaimtiff cannot prove which defendant manufactured the injury-causing product. The court developed a theory of market-share liability first proposed in a student law review note ${ }^{68}$ and based on the Summers doctrine, extended and modified in two key respects.

First, the defendants in Sindell had to shoulder the burden of proof on causation although, im contrast to the circumstances of the Summers case, the DES manufacturers were not shown to be in a "better position" than the plaintiff to offer evidence to determine which of them caused the mjury. ${ }^{69}$ The court recognized that the absence of evidence as to identification is due not to the fault of the defendants, but rather to the passage of time. ${ }^{70}$ Nevertheless, the court determined that the fact that the defendants did not have greater access to mformation to establish the identity of the manufacturer of the DES that allegedly injured the plaintiff should not prevent apphication of the Summers rule on shifting the burden of proof. Second, the Sindell court did not require joimder of all possible defendants. In Sindell, only five out of the hundreds of DES manufacturers were named as defendants. In contrast, in Summers all of the parties who could have been responsible for the plaintiff's mjury were jomed as defendants. ${ }^{71}$

Under the Sindell approach, the plaintiff need only bring before the court those manufacturers that produced a "substantial percentage" of the drug. ${ }^{72}$ Because the possibility that any one of the five defendants manufactured the DES ingested by the plaintiff's mother was so remote, the court thought it unfairly severe to impose complete joimt liability on each defendant unable to exonerate itself. ${ }^{73}$ Rather, the court apportioned liability according to the "likelihood that any of the defendants supplied the product which allegedly injured plaintiff." 74 This likelihood was measured "by the percentage which the DES sold by each of them for the purpose of preventing miscarriage bears to the entire production of the drug sold by all for that purpose."75 Damages thus were apportioned among the defendants based on their share of the market, ${ }^{76}$ with exact damage amounts determined by whether the liability so apportioned is joint, or joint and several. ${ }^{77}$ Finally, the court held that each

68. Comment, DES and a Proposed Theory of Enterprise Liability, 46 FORDHAM L. REV. 963 (1978).

69. Sindell, $26 \mathrm{Cal} .3 \mathrm{~d}$ at 600,607 P.2d at 929, $163 \mathrm{Cal}$. Rptr. at 137.

70. Id. at $601,607 \mathrm{P} .2 \mathrm{~d}$ at $930,163 \mathrm{Cal}$. Rptr. at 138.

71. Id. at 602-03, $607 \mathrm{P} .2 \mathrm{~d}$ at 930-31, $163 \mathrm{Cal}$. Rptr. at 138-39.

72. Id. at $611-13,607 \mathrm{P} .2 \mathrm{~d}$ at $937-38,163 \mathrm{Cal}$. Rptr. at 144-46.

73. Id. at 603, 607 P.2d at 931, $163 \mathrm{Cal}$. Rptr. at 139.

74. Id. at $611,607 \mathrm{P} .2 \mathrm{~d}$ at $937,163 \mathrm{Cal}$. Rptr. at 145 .

75. Id. at 611-12, 607 P.2d at 937, $163 \mathrm{Cal}$. Rptr. at 145.

76. Id. at 612,607 P.2d at 937, $163 \mathrm{Cal}$. Rptr. at 145 .

77. See infra text accompanying notes 82-85. 
defendant could escape liability only by proving that it could not have made the product which allegedly caused the plaintiff's injuries. In DES cases, this can be shown by evidence that the defendant did not market DES in dosages usable for treatment of problem pregnancies at the time or in the location in which the plaintiff's mother purchased the drug, or that the drug manufactured by the defendant was of a different size, shape or color than the drug used by the plaintiff's mother.

An Illinois trial court recently adopted the Sindell theory in a DES case. ${ }^{78}$ The court reiterated the substantial share justification by stating that the inarket-share theory

encompasses the consideration of probabilities and, along with considerations of pohicy, justifies the shifting of the burden [of proof] from one who had no role whatsoever to play in the purchase and consumption of the drug to those who have placed a substantial volume of sales of these products into the stream of commerce. ${ }^{79}$

The court noted that if a plaintiff pleads that the defendants' shares of the total market are substantial, there will be a substantial likelihood that the product actually consumed by the DES mother was made by one of the defendants. The court did not, however, clarify the inany issues left unresolved in the Sindell opinion.

In suni, there are four requirements to a successful use of the theory of inarket-share liability in product liability cases:

(1) injury or illness occasioned by a fungible product (identical-type product) made by all of the defendants joined in the law suit; (2) injury or illness due to a design hazard, with each defendant having sold the same type product in a inanner that inade it unreasonably dangerous; (3) inabihity to identify the specific manufacturer of the product or products that brought about the plaintiff's injury or illness; and (4) joinder of enough of the manufacturers of the fungible or identical product to represent a substantial share of the market. ${ }^{80}$

If these four requireinents are satisfied, each defendant will be liable for the plaintiff's dainages in an amount determined by its share of the relevant niarket, unless a defendant can prove that it could not liave nianufactured the product that caused the plaintiff's harm.

The Sindell market-share theory is one court's attenipt to find a solution to the DES problem. Its inadequacies, however, demonstrate that it is not substantially fairer than any of the coinnion law theories already discussed. First, the Sindell theory presupposes that if there is a substantial share of the market represented in the case, then there is a substantial likelihood that the tortfeasor is actually before the court. But

78. Smith v. Eli Lilly \& Co., No. 80L 20473 (Ill. Cir. Ct. Cook County Oct. 10, 1984).

79. Id., slip op. at 14-15.

80. Prosser \& KeETON, supra note $1, \S 103$, at 714. 
the defendants who happen to be joined as the "substantial share" of the market may be no more responsible for the plaintiff's harm than manufacturers who were not joined as defendants.

The Sindell theory has two other significant inadequacies. First and foremost, not all of the possible defendants are before the court. Second, not all of the defendants have acted in a negligent inanner toward this particular plaintiff. For both of these reasons, a Summers-like shift in burden of proof seems harsher here than it did in the paradigm Summers situation.

In addition, there are numerous unresolved admimistrative problems raised by the Sindell theory. First, it appears (but is not clear from the opinion) that the court intended that the defendants' liability be several, rather than joint and several. Second, the court did not specify how the market-share proof is to be offered and did not define "appropriate market" or "substantial share." Third, the court did not address the issue of the availability of punitive damages under the market-share theory. ${ }^{81}$

Under a theory of several (as opposed to joint and several) marketshare liability, each defendant is liable only for the percentage of the plaintiff's damages that corresponds to the defendant's percentage of the relevant DES market. If the plaintiff does not join all manufacturers of DES, she will not recover $100 \%$ of her damages. Thus, the plaintiff has an incentive to join all defendants that could be responsible for her injuries. Such an approach would increase the likelihood that the manufacturer that made the DES taken by the plaintiff's inother eventually pays damages, and more fairly limits the liability of defendants to actual market share-at the expense, however, of limiting the plaintiff's recovery to less than $100 \%$ of damages suffered.

Under a theory of joint and several market-share liability, a plaintiff may recover $100 \%$ of her damages despite a significant discrepancy between the defendants' actual market-share percentages and the damage apportionment percentages. Since the plaintiff is required to join only those defendants that together represent a "substantial share" of the DES market, each defendant may be liable for a portion of the plaintiff's damages that substantially exceeds the defendant's market share. ${ }^{82}$ If,

81. The California Court of Appeal recently held that no punitive damages may be awarded in a case based upon the market-share habihity theory. Magallanes v. Superior Court, $213 \mathrm{Cal}$. Rptr. 547 (Cal. Ct. App. 1985).

These issues have been widely discussed. See, e.g., Robinson, Multiple Causation in Tort Law: Reflections on DES Cases, 68 VA. L. REV. 713 (1982); Comment, Market Share Liability_Proposals for Applications, 19 AM. Bus. L.J. 523 (1982); Note, Industry-Wide Liability and Market Share Allocation of Damages, 15 GA. L. REv. 423 (1981); Note, Market Share Liability: A Plea for Legislative Alternatives, 1982 U. ILL. L. REv. 1003 [hereinafter cited as Note, Legislative Alternatives]; Note, Market Share Liability Adopted to Overcome Defendant Identification Requirement in DES Litigation, 59 WASH. U.L.Q. 571 (1981).

82. Comment, supra note 64 , at 631 . 
for example, the plaintiff joins two defendants, each with $35 \%$ of the market share, each defendant will be liable for $50 \%$ of the plaintiff's damages. This discrepancy decreases as the total market share of the defendants approaches $100 \%{ }^{83}$

In resolving this issue of interpreting Sindell, soine commentators have suggested that "the court did not intend to provide for joint and several hability, but each defendant is liable for the proportion of plaintiff's damage equal to the defendant's proportionate market share." 84 This might be inferred from the fact that the Sindell court rejected the concert of action and enterprise hability theories because the drug coinparies had not acted as joint tortfeasors. ${ }^{85}$ The first California trial court interpreting Sindell to address this issue also ruled, in a preliminary order determining issues, that liability should be several and not joint. ${ }^{86}$ Although this issue was raised again by defendant drug companies in a California Court of Appeal case, ${ }^{87}$ no California appellate court has yet addressed it.

The second issue unresolved in Sindell is interpreting the requirement that the plaintiff join drug companies representing a substantial share of the "appropriate market." The Sindell court defined that market $\mathrm{m}$ terns of the use of the product, ${ }^{88}$ but provided neither geographic nor temporal limits for the concept. ${ }^{89}$

Finally, the Sindell court did not indicate how market shares are to be determined and did not address the practical difficulties in proving

83. Id.

84. Prosser \& KeEton, supra note $1, \S 103$, at 714.

85. Sindell, 26 Cal. 3d at 606, 609, 607 P.2d at 933, 935, 163 Cal. Rptr. at 141, 143.

86. Den Daas v. Boyle Drug Co., No. 73275 (Cal. Super. Ct. Ventura County Oct. 1, 1984) (order determining issues). The court explained that joint liability would defeat the entire proration concept that is the core of the Sindell market slare decision.

87. The defendants in Magallanes v. Superior Court, 213 Cal. Rptr. 547 (Cal. Ct. App. 1985), suggested that liability was several in their brief on plaintiffs petition for writ of mandate. See Whether Punitive Damages Can Be Awarded Under Sindell Is Issue in Dispute, DES LITIGATION REP. (Andrews Publications) 5137, 5139. Defendants argued that the languagc in the Sindell opinion clearly suggests several liability, and in addition note that Justice Stanley Mosk, author of the Sindell opinion, stated that "we felt that it would be only fair to limit liability by the percentage of the inarket by which any inanufacturer was responsible," Trends in Product Liability Litigation, TRIAL, Nov. 1980, at 82, 84. DES LITIGATION REP. at 5139.

88. Sindell v. Abbott Laboratories, 26 Cal. 3d 588, 612, 607 P.2d 924, 937, 163 Cal. Rptr. 132, 145. The appropriate inarket includes all inanufacturers of DES for the purpose of preventing miscarriage.

89. The court did explicitly indicate, lowever, that a defendant inay exculpate itself by showing that it did not market DES until after the time in whicl plaintiff's mother purchased the drug. Id.

A California trial court interpreting Sindell has ruled that the "appropriate inarket" is the sinallest market that fairly covers the plaintif's involvement with the subject drug. Den Daas v. Boyle Drug Co., No. 73275 (Cal. Super. Ct., Ventura County, Oct. 1, 1984) (order determining issues). In this case, the court lield that the appropriate inarket was the military market during the years 1955 through 1958. 
market shares.90 The Sindell court did not even define the term "substantial share," been suggested that the substantial share requirement exists so that "more likely than not the culpable party is one of the defendants and will not escape all responsibility, and, therefore, substantial share ought to mean more than $50 \%$ of the market." 92 The commentator cited by the Sindell court suggested that 75 to $80 \%$ of the market must be joined; ${ }^{93}$ a California trial court interpreting Sindell has held that a "substantial share" of the market is a minimum of $51 \%$ of the relevant inarket, but that the percentage may be increased upon an appropriate showing in a particular case. ${ }^{94}$

Perhaps because the Sindell theory has so many unresolved issues and remains only partially developed by the California courts, it has been widely rejected outside of California. ${ }^{95}$ Both courts and commentators have recognized that the market-share approach is not suitable for product liability cases where the products or the alleged defects are not identical. ${ }^{96}$

The theory also has generated widespread criticism on related policy

90. See Downey \& Gulley, Theories of Recovery for DES Damage: Is Tort Liability the Answer?, 4 J. LEGAL MED. 167 (1983).

91. Sindell, $26 \mathrm{Cal} .3 \mathrm{~d}$ at $612,607 \mathrm{P} .2 \mathrm{~d}$ at 937, $163 \mathrm{Cal}$. Rptr. at 145.

92. Prosser \& Keeton, supra note $1, \S 103$, at 714.

93. Comment, supra note 68 , at 996.

94. Den Daas v. Boyle Drug Co., No. 73275 (Cal. Super. Ct. Ventura County Oct. 1, 1984) (order determining issues). This court stated that the threshold question of whether or not the plaintiff has brought into the action a substantial share of the market is a mixed question of law and fact to be determined by the court. Id. at 2 .

95. See, e.g., Mizell v. Eli Lilly \& Co., 526 F. Supp. 589,596 (D.S.C. 1981); Zafft v. El Lilly \& Co., 676 S.W.2d 241, 246 (Mo. 1984). One court has indicated that on an adequate record it might allow recovery under a market share theory. Payton v. Abbott Laboratories, 386 Mass. 540, 574, 437 N.E.2d 171, 190 (1982). The Michigan Supreme Court has refused to consider the theory absent its explicit presentation. Abel v. Eli Lilly \& Co., 418 Mich. 311, 337, 343 N.W.2d 164, 176 (1984). Finally, one appellate court has deferred to the state supreme court or legislature as the "appropriate tribunal" for the consideration of such a claim. Namm v. Charles E. Frosst \& Co., 178 N.J. Super. 19, 35, 427 A.2d 1121, 1129 (App. Div. 1981).

96. See, eg., Note, Market Share Liability: An Answer to the DES Causation Problem, 94 HARV. L. REV. $668,678-79$ (1981). In contrast to DES pills, which "are assumed to be equally harmful with respect to the market as a whole, [and wherel the total volume of DES marketed corresponds directly to the amount of risk created," the theory is not suited to circumstances "in which the product in question is not uniformly harmful, . . . since the total risk created by any manufacturer would be a function of both its share of the market and the relative harmfulness of its product." Id. at 679; see also Sheffield v. Eli Lilly \& Co., 144 Cal. App. 3d 583, 592-99, 192 Cal. Rptr. 870, 875-80 (1983) (market-share theory rejected where plaimtiff was injured by defectively manufactured polio vaccine). Recently, several courts have ruled that the market-share theory should not be extended to asbestos cases. See, e.g., Thompson v. Johns-Manville Sales Corp., 714 F.2d 581 (5th Cir. 1983); Hannon v. Waterman S.S. Corp., 567 F. Supp. 90, $92-93$ (E.D. La. 1983); Starling v. Seaboard Coast Liue R.R., 533 F. Supp. 183, 186-91 (S.D. Ga. 1982). The Hannon and Starling decisions retied in part on the nonfungibility of asbestos fibers, as compared with DES. Hannon, 567 F. Supp. at 92; Starling, 533 F. Supp. at 191. Accord, Prosser \& KeEton, supra note $1, \S 103$, at 714 (it might be inappropriate "to apply this fungible product conccpt to asbestos- 
grounds. It has been criticized as encouraging plaintiffs to perjure themselves by concealing evidence as to the identity of the manufacturers responsible for their injuries, where the companies have since gone out of busmess or are judgment-proof, in order to sue under the market-share theory. ${ }^{97}$ It also lias been pointed out that imposing the market-share theory in a strict liability tort case "gives rise to a form of absolute liability by relieving the plaintiff of proving defendant's breach of duty and by guaranteeing plaintiff's proof of causation," which "forces an industry into the position of an insurer" of a product. ${ }^{98}$ The theory has also been criticized as not serving the goal of economic efficiency. By apportioning damages througliout an industry solely on the basis of market shares and irrespective of safety efforts, it enables unsafe manufacturers to spread the burden of their accident costs and thereby creates disincentives for safety. And as pointed out above, the theory raises formidable problems of both fairness to defendants and judicial administration by increasing the number of defendants in the courtroom, placing the burden of identification on the defendants without regard to the relative abilities of the parties to identify the actual responsible producer, and embroiling the court in the coinplexities of defining the relevant market.99

In short, the Sindell approach, while solving some problems, leaves a host of others unanswered. Not surprisingly, courts have further modified the Summers approach as glossed by Sindell—with improved, albeit still inadequate, results.

\section{E. Variations on Sindell Market-Share Theory}

\section{Market-Share Alternative Liability}

In the recent case of Martin $v$. Abbott Laboratories, ${ }^{100}$ the Washington Supreme Court adopted a modified version of the Sindell marketshare approacl, rejecting the Sindell theory because of "its inherent distortion of hability."101 This nodified Sindell theory permits a plaintiff to bring suit against a single drug company or several drug companies by alleging the following elements: (1) plaimtiff's nother took DES; (2) DES caused the plaintiff's subsequent injuries; (3) defendant produced or marketed the type of DES taken by the plaintiff's mother," ("e.g., dosage, color, shape, inarkings, size, or other identifiable characteristics"), and

containing products because they are by no means identical since they contain widely varying amounts of asbestos").

97. Note, supra note 96 , at 676 .

98. Note, The Market Share Theory: Sindell's Contribution to Industry-Wide Liability, 19 Hous. L. REV. 107, 135-136 (1981).

99. Note, Market Share Liability for Defective Products: An Ill-Advised Remedy for the Problem of Identification, 76 Nw. U.L. REv. 300, 323-26 (1981).

100. 689 P.2d 368 (Wash. 1984).

101. Id. at 380 . 
(4) defendant's conduct in producing or marketing DES constituted a breach of a legally recognized duty to the plaintiff. ${ }^{102}$ Moreover, "the plaintiff need not allege or prove any facts related to the time or geographic distribution of the subject DES."103

Under this theory, defendants may escape liability by showing that they did not manufacture the type of DES taken by the plaintiff's mother or did not market DES at the relevant time or in the relevant geographic area. Those defendants who cannot exculpate themselves will be presumed, initially, to have equal market shares, and will be liable in equal shares for the plaintiff's total damages. Each defendant may reduce its liability by proving that its actual market share is less than its presumed share. The defendants who are not able to produce evidence of their actual market shares will be hable for the remainder of the plaintiff's damages in excess of the other defendants' actual market shares. ${ }^{104}$

The court illustrated how this rule of apportionment would work in a hypothetical case where the plaintiff's damages are $\$ 100,000$. If the defendants, $X$ and $Y$, are unable to establish their actual market shares, each will be liable for $50 \%$ of the judgment. If $X$, on the other hand, establishes that its actual share of the relevant market is $20 \%, X$ is liable for $20 \%$ of the plaintiff's damages and $Y$ is hable for the remaining $80 \%$. If, however, $X$ establishes that its actual market share is $20 \%$ and $Y$ establishes that its actual market share is $60 \%$, then $X$ is hable for $20 \%$ of the damages and $Y$ is liable for $60 \%$. In this situation, the plaintiff will not recover $100 \%$ of her damages because the remaining $20 \%$ of the market consists of manufacturers who were not joined in the suit. ${ }^{105}$ In contrast to Sindell, under which it is unclear whether the plaintiff recovers $100 \%$ of her dannages, this market-share alternative hability theory awards a plaintiff $100 \%$ of her damages unless all the named defendants are able to prove their actual market shares. Further, "defendants may implead third party defendants in order to reduce their presumptive share of the market or in order to establish an actual reduced market share." 106

The Martin court specifically rejected the Sindell requirement that the plaintiff join defendants representing a "substantial" share of the market. ${ }^{107}$ The court stated that "[n]ot only does the Sindell court fail to define 'substantial' share of the relevant market, the theory distorts market liability by providing that the 'substantial' market share bears joint

102. Id. at 382.

103. Id.

104. Id. at 382-83.

105. Id. at 383.

106. Id.

107. Id. at 382. 
responsibility for 100 percent of plaintiff's injuries." 108

The court justified its theory in part on the basis that all the defendants contributed to the risk of injury, even though they might not have contributed to the actual injury of a given plaintiff. ${ }^{109}$ Furthermore, the court assumed that a "drug company is in a better position to absorb the cost of the injury" because it "can either insure itself against liability, absorb the damage award, or pass the cost along to the consuming public as a cost of doing business." 110 And the court pointed out that while "elimination of individual causal responsibility as an element of plaintiff's case is liability enhancing," the apportionment of damages according to respective market shares and the possibility that the plaintiff might not recover her entire damages if all defendants can prove their actual market shares is "liability limiting." 111

The Martin approach refines the Sindell market-share theory and provides a fairer result. It is based on the presumption that DES inanufacturers should pay damages because they contributed to the risk of injury to the public and not because they are actually responsible for a particular plaintiff's injuries. Aside from its inconsistency with traditional principles of tort law, the Martin theory leads to a fairer result than the other theories discussed above. It clearly establishes that the defendants will be severally liable, which ensures that the damages they pay will be limited to the risks they actually caused. It permits the defendants to exonerate themselves, which ensures that the defendants who clearly are not responsible for a plaintiff's harm will not pay damages.

On the other hand, the lack of a requirement that the plaintiff join the defendants representing a substantial share of the market creates the possibility that the joined defendants who are unable to prove their actual market shares will be forced to pay damages greatly disproportionate to their contribution to the risk of injury to the public. In addition, problems in judicial administration remain. The court did not define the relevant market for the purpose of apportioning market shares, either in terms of time or geography. Moreover, while a defendant is permitted to produce evidence to reduce its presumptive market share, the court did not indicate whether a plaintiff may produce evidence showing that a defendant's actual inarket share is greater than its presumptive market share. Furthermore, the theory raises a possibility that a plaintiff will recover less than $100 \%$ of her damages.

Most significantly, the presumption that manufacturers should pay

108. Id. at 381 .

109. Id. at 382.

110. Id.

111. Id. at 383 . 
damages for contributing to the risk of injury to the public overrides the basic principle of tort law that one who is responsible for causing a harm sliould pay for the resulting injury. ${ }^{112}$ Creating a risk that does not result in specific damage is simply not a tort. This type of conduct, when wrongful, is more in the bailiwick of criminal law, as with a drunk driver whose recklessness does not result in an injury.

\section{Risk Contribution Theory}

In Collins v. Eli Lilly Co. ${ }^{113}$ the Wisconsin Supreme Court rejected the plaintiff's proposed theories of alternative liability, concerted action, enterprise liability, and inarket-share liability, and framed a new inethod of recovery for DES plaintiffs in Wisconsin, purportedly based on the state's existing comparative negligence laws. The court noted that this method of recovery could apply to other product hability actions in situations which are factually similar to DES cases. ${ }^{114}$ The plaintiff must allege the following elements: (1) plaintiff's mother took DES; (2) DES caused the plaintiff's subsequent injuries; (3) defendant produced or marketed the type of DES taken by the plaintiff's inotlier (e.g., color, sliape, markings, size, or otlier identifiable cliaracteristics); and (4) defendant's conduct in producing or inarketing the DES constituted a breacli of a legally recognized duty to the plaintiff. ${ }^{115}$ Witl respect to the third element, the plaintiff inay satisfy the requirement even if she cannot prove what type of DES lier mother took; slie need only "prove that the defendant . . . produced or marketed the drug DES for use in preventing miscarriages during pregnancy." 116

If the plaintiff is able to prove these four elenents, sle may recover her entire damages from a single defendant. In this key respect, the Collins rule is tougher for defendants than the Sindell rule. ${ }^{117}$ If, however, the plaintiff joins inore than one drug company, the damages will be apportioned among the defendants by the jury. In determining the percentage of liability to assign to each defendant, the jury may consider a

112. See authorities cited supra note 2.

113. 116 Wis. $2 d 166,342$ N.W.2d 37 (1984).

114. Id. at 181,342 N.W.2d at 49.

115. Id. at 193, $342 \mathrm{~N} . \mathrm{W} .2 \mathrm{~d}$ at 50 . A plaintiff may proceed under theories of negligence and strict liability. Under a negligence theory, the plaintiff will have to prove that a drug company breached a duty of care when it made or sold DES. Under a strict liability theory, the plaintiff must show that the DES was defective, that it was unreasonably dangerous, that the defect was the cause of plaintiff's injuries, that the company engaged in making or selling the drug, and that the company expected the DES to reach the consumer without substantial change. Id. at $195-96,342$ N.W.2d at 51.

116. Id. at $193-94,342$ N.W.2d at 50.

117. Id. at 194, 342 N.W.2d at 50-51. "[A]ny defendant may . . . implead as third-party defendants other drug companies which it can allege produced or marketed the type of DES taken by the plaintiffs mother." Id. at 195,342 N.W.2d at 51 . 
number of factors, one of which is whether the defendant had a small or large share of the relevant market. The other factors include, but are not limited to, the following:

whether the drug company conducted tests on DES for safety and efficacy in a use for pregnancies; to what degree the company took a role in gaining FDA approval of DES for use in pregnancies; . . . whether the company took the lead or merely followed the lead of others in producing or marketing DES; whether the company issued warnings about the dangers of DES; whether the company produced or marketed DES after it knew or should have known of the possible hazards DES presented to the public; and whether the company took any affirmative steps to reduce the risk of mjury to the public. ${ }^{118}$

The court noted that a "DES plaintiff, who was a fetus at the time the DES was taken, could [not] be attributed with . . . negligence," and "that in all DES cases [presumably] 100 percent of the liability will be apportioned only among the defendants." 119

The Collins theory is even less fair to defendants than the other theories discussed above. A manufacturer who is the sole defendant in an action will pay damages far in excess of its share of the market and far in excess of the risk of injury it created. Moreover, it will incur all the litigation costs in defending the case. Under this theory, a manufacturer who did not manufacture the actual injury-inflicting drug could be forced to pay $100 \%$ of the plaintiff's dainages as well as its own transaction costs for the action. Unless the manufacturer impleads other drug compames that it can allege produced the type of DES ingested by the plaintiff's nother, it will be liable for the plaintiff's entire damages. The procedure seems unfair particularly because the plaintiff, who is in a better position to prove the type of DES ingested by her inother, need only prove that the defendants she joins produced or marketed DES for use in pregnancy problems. Thus, the plaintiff easily could join a number of defendatns. Once again, the court's atteinpt to provide compensation to an innocent plamtiff demonstrates that a judicial scheme for recovery in DES cases may be developed only at the cost of unfairness to defendants.

III

\section{A Framework For a Legislative Solution to the IDENTIFICATION PROBLEM}

The above analysis of the various theories courts have developed to provide compensation for persons suffering injuries allegedly caused by

118. Id. at 200,342 N.W.2d at 53 .

119. Id. at $200 \mathrm{n} .14,342 \mathrm{~N} . \mathrm{W} .2 \mathrm{~d}$ at $53 \mathrm{n} .14$. The court stated that punitive damages may not be awarded to a plaintiff who recovers under this theory, however, because the concept of punitive damages is based on the notion "that the wrongdoer being punished because of his conduct actually caused the plaintiff's injuries." Id. at 202,342 N.W.2d at 54. 
DES shows that the judicial system is unable adequately to resolve the DES identification problem. In many cases, particularly those involving clear-cell adenocarcmoma, the plamtiffs can allege all elements of a tort cause of action except the identity of the actual wrongdoer. Some courts appear to be motivated by a desire to "compensate" injured persons but are restrained by the traditional rules that impose hability only on those who are the cause-in-fact of a harm. To the extent that courts have overridden the traditional rules, probleins of fairness to defendants have arisen.

The majority of courts have followed the traditional approach, requiring a DES plaintiff to produce evidence of the identity of the manufacturer of the particular pills that allegedly caused her mjury. For instance, courts in Missouri, South Carolina, Texas, New Jersey, Florida, Massachusetts, Connecticut, and the District of Columbia have demed recovery to plaintiffs who could not identify the manufacturer of the DES that allegedly caused their injuries. ${ }^{120}$ The courts that have permitted recovery for the plaintiffs who are unable to identify the manufacturer of the drug have reached outside the traditional tort system to do so. They have modified traditional joint hability theories and have developed new theories, all of which conflict with the basic tort notion that one who is responsible for causing a harm should pay. On their faces, these theories are unfair to defendants. In addition, the theories raise substantial problems of judicial administration. Theories such as the Sindell market-share theory and the Martin market-share alternative liability theory were not fully developed or explained by the courts, creating inany probleuns for other courts wishing to follow these approaches. Furthermore, application of these theories involves practical problems in apportioning dainages according to the defendants' market shares. The process of determining the relevant market and the defendants' market shares in individual cases will involve lengthy hitigation and huge transaction costs for all parties.

A number of cominentators have recognized the inability of the tort litigation system to resolve the identification problem and have advocated various alternative systems of recovery. ${ }^{121}$ The alternatives pro-

120. See Gullotta v. Eli Lilly \& Co., DES LITIGATION REP. (Andrews Publications) 6061 (D. Conn. 1985); Morton v. Abbott Laboratories, 538 F. Supp. 593 (M.D. Fla. 1982); Pipon v. Burroughs-Wellcome Co., 532 F. Supp. 637 (D.N.J. 1982); Mizell v. Eli Lilly \& Co., 526 F. Supp. 589 (D.S.C. 1981); Ryan v. Eli Lilly \& Co., 514 F. Supp. 1004 (D.S.C. 1981); Gray v. United States, 445 F. Supp. 337 (S.D. Tex. 1978); Payton v. Abbott Laboratories, 386 Mass. 540, 437 N.E.2d 171 (1982); Zafft v. Eli Lilly \& Co., 676 S.W.2d 241 (Mo. 1984); Namm v. Charles E. Frosst \& Co., 178 N.J. Super. 19, 427 A.2d 1121 (App. Div. 1981).

121. See, e.g., Biebel, DES Litigation and the Problem of Causation, 51 INS. Couns. J. 223 (1984); Delgado, Beyond Sindell: Relaxation of Cause-In-Fact Rules for Indeterminate Plaintiffs, 70 CALIF. L. REv. 881 (1982); Downey \& Gulley, Theories of Recovery for DES Damage: Is Tort Liability the Answer?, 4 J. LEGAL MED. 167 (1983); Fischer, Products Liability-An Analysis of 
posed include legislative and administrative schemes, such as a limited no-fault product hability fund for the plaintiffs unable to identify the manufacturer of a generic product that produced a latent injury, suits against the federal agency responsible for regulating the particular industry using the Federal Tort Claims Act and the Administrative Procedure Act; ad hoc congressional responses to mass injuries caused by products of unidentifiable manufacturers; legislation designed to hold certain industries liable through trade associations for all injuries caused by those industries' products whenever the manufacturer of an injury-causing product is not identifiable; a no-fault conipensation systen for persons injured by DES which would be funded by a tax imposed upon all manufacturers who produced DES for use as a miscarriage preventative; and a toxic tort compensation system not limited to a single industry or a single type of product-injury but designed to deal with the toxic tort problem as a whole.

Ideally, the identification problem in DES cases should be solved by legislation. The legislation's goal should be to provide a speedy and efficient process for dealing with claims where the injured person cannot identify the nianufacturer of the allegedly injury-causing product. It should solve the problenis created by the court-made solutions to the nonidentification cases, while providing fair and adequate conipensation to mjured persons. Before examining the broad framework of a legislative solution to accomplish these two goals, however, it is necessary to define precisely the limited scope of a solution to the DES problem.

\section{A. Limiting the Scope of a Legislative Solution to the Identification Problem}

A legislative systen1 should serve only as an alternative method of providing conipensation to injured persons who are unable to prove the identity of the responsible inanufacturer. It is important that the legislative solution not preempt tort suits where identification is possible. It would be unfair to require nonresponsible manufacturers to bear the burden of compensating injured persons, through the legislative system, in cases where the responsible nianufacturer can be identified. Unfairness also would result if the legislative solution were to permit manufacturers responsible for causing harms to escape tort liability. Furthermore, it would be administratively inefficient to overload the legislative conipen-

Market Share Liability, 34 VAND. L. REv. 1623 (1981); Roberts \& Royster, DES and the Identification Problem, 16 AKron L. REv. 447 (1983); Comment, Industry-Wide Liability: Solving the Mystery of the Missing Manufacturer in Products Liability Law, 38 WASH. \& LEE L. REv. 139 (1981); Note, Industry-Wide Liability, 13 SuFFoLK U. L. REV. 980 (1979) [hereinafter cited as Note, Industry-Wide Liability]; Note, Legislative Alternatives, supra note 81. 
sation system with cases that currently are handled appropriately by the judicial tort system.

To accomplish this important goal, legislation could encourage those persons who truly are able to identify the manufacturer to do so by requiring identification of the manufacturer for recovery under traditional tort principles. Thus, persons who can prove the identity of the responsible manufacturer could sue that manufacturer for tort damages, including pain and suffering. Where persons are unable to prove the identity of the responsible manufacturer (i.e., "nonidentification claims"), they could be compensated under the legislative system for outof-pocket losses. In nonidentification cases, the claimant should be required to show fault, causation, damages, and a good-faith, genume attempt to identify the manufacturer. Proof of these elements could trigger compensation through the legislative mechanism. Moreover, the legislation should impose penalties on claimants and unscrupulous counsel who falsely identify a defendant. This may occur because a greater recovery would be available to a claimant who can make a proper identification. If a court determines that a false identification has been filed, the defendants' legal costs should be borne by the plaintiff and, in appropriate cases, a civil fine should be imposed on the plaintiff's counsel.

A separate but related problem exists in cases where the claimant can identify a defendant but is unable to recover in the tort system because the defendant is insolvent or judgment-proof. These claimants may be denied any recovery, while claimants who caimot identify a defendant may recover under the legislative solution. The legislative solution should address this issue to avoid this unfair result and, again, to forestall false claims. One solution may be to permit these claimants to recover under the legislative system for out-of pocket losses.

Moreover, legislative energy should be focused on addressing the identification problem. The identification requirement presents a unique problem in cases involving latent injuries linked to a generic product such as DES. The elements of fault and causation are not peculiar to these cases. Thus, a basic premise of the legislative solution must be that an injured person is required to prove that the product actually caused his or her injury.

In addition, and also in connection with the scope of the legislative solution, consideration should be given to the amount of payment to be received by claimant. The system should provide a smooth and efficient means whereby persons who (in most jurisdictions) are excluded from the possibility of payment would receive an award. Even in jurisdictions that currently perinit such persons to secure an award under the tort system, delays and other deficiencies would be mitigated by a legislative solution. The system is "standby equipment" for the tort system, a vehi- 
cle to provide relief where the tort litigation system fails. The damage award should reflect that fact and be limited to the claimant's true excess economic losses. This would mclude amounts lost and not otherwise recovered through collateral sources, but would not include dannages for pam and suffering.

Finally, careful consideration should be given to how claimants enter the system. It is contemplated that the system would serve only those who have a problem identifying the defendant who made the product; individuals with problems relating to basic causation (i.e., whether the product caused the injury) or nonliability (i.e., whether the defendant, if he can be identified, owed no duty to the plaintiff) would be excluded. The simplest approach is to let the current court system handle these matters, but they are part of an area that must be addressed.

\section{B. The Legislative Framework}

Given the narrow focus of an appropriate legislative solution, it is important to sketch a framework for construction of the solution. First, let us quickly recall the problems such a solution can face, as revealed by the courts' difficulties im fashioning a common law solution to the DES problem. The difficulties presented by the judicial theories create three undesirable results - unfairness to defendants, incomplete compensation for the plamtiffs, and mefficiencies in judicial administration. The following list summarizes the most significant problems of the judicial theories and their adverse results:

1. Alternative liability theory, Sindell theory, Martin theory, Collins theory: Not all parties who may have been responsible for the plaintiff's harm are required to be joined as defendants. Thus, the responsible party may escape liability and the joined defendants may be forced to pay damages even though none of them caused the plaintiff's harin. Result: Unfairness to some joined defendants and imperfect deterrence of tortious conduct.

2. Alternative liability theory: The burden of proving identification is shifted to the defendants. In DES cases, the defendants are not in a better position to provide all relevant evidence. As to some of this information, it would be fairer and more efficient to place the burden of proving identification on the plaintiff, who has better access to the type of drug taken by her mother, her mother's geographic location at the time of ingestion, the location, etc. Result: Unfairness to the defendants, inefficiency in judicial administration, and impairnent of the deterrence function.

3. Alternative hability theory: The theory presupposes that all defendants have acted negligently toward the plaintiff and thus 
shifts the burden of proof unfairly. Manufacturers of drugs not taken by the plaintiff's mother have not acted negligently toward the plaintiff, so no shift in the burden of proof should follow. Result: Unfairness to defendants and imperfect deterrence of tortious behavior.

4. Concert of action theory: The theory applies only where there has been a tacit agreement to act wrongfully and, thus, the parties to the agreement are joint tortfeasors and all are responsible for the acts of the others. There was no tacit agreement ainong the manufacturers of DES. Accordingly, one manufacturer is not responsible for the acts of the others. Result: Unfairness to defendants.

5. Enterprise liabihity theory: There are no centralized industry standards and, thus, no basis for enterprise liability on a theory of jomt control through uniform imdustry standards. Result: Unfairness to defendants.

6. Sindell theory: Appoimtment of damages throughout an mdustry solely on the basis of market shares, irrespective of safety efforts, is economically inefficient and puts those manufacturers who have made little or no effort to market a safe product in the same position as those who did make safety efforts. Result: Unfairness to some defendants and impairment of the deterrence function.

7. Sindell theory: The requirement that the plaintiff join a substantial share of the market increases the number of defendants in the courtroom im each case. This increases admmistrative costs. Result: Inefficient judicial administration.

8. Sindell theory, Martin theory, Collins theory: The definitions of substantial share and the relevant market are not clear. Thus, the court is forced to become embroiled in the complexities of defining these terms im each case. Result: Inefficient judicial administration.

How might a legislative solution resolve these difficulties? Problems 4 and 5 are insoluble, because they mdicate that the concert of action and enterprise liability theories do not justify imposing liability. Thus, the only justifiable forms of recovery are those within the confines of Summers, and the inodifications thereof.

Problem 1 could be solved if all defendants could be identified in advance of litigation. A legislative solution could achieve this result through a one-time centralized set of findings of fact.

Problems 2 and 3 could be solved if the burden of producing evidence were placed on defendants only when information was in their control, and only if and to the extent that the defendants had breached at 
the very least some duty of care to someone. This could be accomplished legislatively by predetermining which issues will be resolved on a centralized basis among defendants, and by apportioning costs of administration among defendants in proportion to their tortious behavior and market shares. Problems 6, 7, and 8 would also be solved by such a centralized set of findings of fact and a liability and market-share apportionment of administrative costs. Thus, if a legislative solution adheres to the basic guidelines relating to centralized fact-finding and apportionment of costs, it could achieve what each of these theories of recovery attempts to achieve, but in fact achieves ouly imperfectly.

Witl1 the lessons of the common law solutions clearly in mind, let us proceed to delineate a set of guidelines for a legislative solution to the DES problein.

First and foremost, careful consideration should be given to whether, low, and to what extent legislation will require manufacturers to contribute to compensation paid to plaintiffs. To require all manufacturers of DES (or the product in question) to contribute to the compensation paid to plaintiffs in nomidentification cases would be fairer than the random targeting of defendants that occurs under current judicial theories. A inajor criticisin of courts' approaches is that they impose liability on manufacturers that are not responsible for causing a plaintiff's harm. There are over 300 DES inanufacturers wlio inay have been responsible, yet the judicial theories impose liability only on the handful of manufacturers that have been singled out as defendants. The defendants may be no more responsible than other DES manufacturers who were not joined in a lawsuit, yet the defendants are forced to pay dainages. The unfairness results because some nonresponsible manufacturers pay damages and legal costs while other responsible manufacturers do not. Requiring joinder of all DES manufacturers in every court case would often be inipossible, would always be inefficient, would inpose great burdens on plaintiffs, and would create problems in judicial administration. A legislative solution, on the other hand, could avoid both an unfair result and problens in inefficiency of administration because it could require payment of nonidentification clainis by all DES manufacturers.

Thus, consideration should be given to whether contribution to coinpensation for plaintiffs should be inade solely by industry or also by governinent. Some commentators have called for development of compensatory funds to be financed by special taxes on an industry or by the federal government, or have called for trade associations to establish their own compensation funds througl1 a self-imposed excise tax. ${ }^{122}$ The legislative approach recommended in this Article, however, focuses on

122. See, e.g., Note, Legislative Alternatives, supra note 80, at 1037-42. 
payment of compensation to claimants, either directly or indirectly, by the manufacturers themselves, thus furthering the cause of effective deterrence of (and where appropriate, penalty for) tortious behavior. In sum, the source of payment is a key issue that legislation drafters must resolve. If there is active participation im the development of a drug by the government, serious consideration should also be given to utilizing the tax base as a part of the compensation fund. In such a situation, responsibility is, in part, public.

Assuming responsibility for causing a claimant's harm would not be the sole basis for requiring payment, the legislation could rely on some other fair basis for requiring all DES manufacturers to pay compensation im nonidentification cases. One possible solution is to require all manufacturers of DES to make contributions in each nonidentification case. Alternatively, the legislation could require periodic payments by all DES manufacturers to a central account or fund that would distribute compensation to successful claimants im nonidentification cases. Assessments against all DES manufacturers in nomidentification cases could be based on soine combination of the market-share theories developed by the courts. For example, legislation could apportion compensation claims among all manufacturers of DES based on a number of factors, including the following: (1) the manufacturer's share of the market for the product, (2) the degree of the manufacturer's culpability, (3) the manufacturer's good faith or bad faith in remedying the product and in responding to claims. ${ }^{123}$

Second, the above discussion of the market-share theories applied by courts concluded that consideration of market sliare and other factors in individual cases is inefficient and creates problems in judicial administration. ${ }^{124}$ Furthermore, the judicial market-sliare theories require proof of the relevant market and joinder of a substantial share of the relevant market. Legislation requiring apportionment of claims in nonidentification cases according to market shares and other criteria, however, can and should strive to reduce these problems. Specific guidelines in the legislation itself for defining the relevant market or markets would resolve that issue; the question of what constitutes a "substantial share"

123. One commentator has suggested a "latent technological injury compensation" system for plaintiffs who suffer from injuries not by their nature discoverable within the runuing of the statute of limitations. These plaintiffs would apply for relief to an administrative tribunal and be compensated by funds from a tax paid by all (presumably by all DES) manufacturers. Note, Industry-Wide Liability, supra note 121, at 1015-22. This solution suffers from a defect of the common law solutions: it imposes a tax on all DES manufacturers regardless of market share, fault, or responsiveness to claims. For further criticisms of this scheme, see Note, Legislative Alternatives, supra note 81, at 1023-24. (The note proposes a legislative solutiou requiring a trade associatiou-funded compensation pool, id. at 1037-42, which suffers from the same defect).

124. See supra notes 67-119 and accompanying text. 
of the market would be immaterial because the legislation would apportion compensation claims among all manufacturers in the relevant market or markets.

A further problem inherent in the judicial market-share theories is the hitigation of market shares in every case. Under a legislative solution, however, the apportionments for the relevant market or markets need not be made repeatedly in each nonidentification case but could be made only once or on a defined schedule on the basis of administrative or arbitration procedures. Any acceptable legislation must develop and set forth carefully drafted provisions embodying such procedures. The legislation should require participation in the hearings by all manufacturers in the relevant market or markets. Consideration should be given to whether a method could be developed for nonadversarial hearings; the hearings' sole purpose could be to receive evidence on the factors that will determine the apportionments. In situations where the manufacturers are in a better position to prove the factors relevant to determining apportionment, it would be appropriate for the inanufacturers to do so. Provisions could be mcluded in the legislation to permit modification of the apportionments if new evidence emerges at a later time. Such administrative or arbitration procedures could of course be displaced by a suitably structured, suitably publicized civil quasi-class action-another possibility for a legislature to consider.

The legislation could also establish a inechanism to make assessments on manufacturers based on the apportionments developed in such hearings that would provide a method for transferring payment to claimants in nomidentification cases. This could be accomplished by making assessments, in accordance with the apportionments developed in the hearings, for each nomidentification case. On the other hand, a careful legislative examination of the facts may show that it would be best to have the assessments made periodically and transferred to an account or fund for distribution to imdividual claimants.

A fourth, related guideline for a legislative solution is that the legislation should fairly apportion transaction costs among all manufacturers of a product. The legislation should address the issue of when, how, and by whom counsel participating in the system should be paid. This aspect of the legislation focuses primarily on the role of counsel representing defendants. The legislation should provide a method for spreading the costs of nonidentification cases among all manufacturers of the product. It would be inefficient to require joinder of all manufacturers of a product in every lawsuit where the plaintiff is unable to identify the manufacturer. Thus, the legislation should include a set of provisions that address the issue of who should defend the action (for the purpose of litigating causation, fault, and damages) when a plaintiff is unable to 
prove that one of the named defendants manufactured the product alleged to have caused her injury. Defense counsel that litigate these issues should be paid through the legislative system.

Assessments for litigation costs could be made on all manufacturers of the product in some fair way, perhaps based upon the apportionments made in the centrahized findings of fact. Counsel's rates should be computed in proportion to the rates in the market in which they operate. Counsel should be required to keep detailed hourly records subject to review at the discretion of judges. A staff of defense counsel representing the legislative compensation system might be set up that would, in effect, represent all manufacturers of the product. Another possibility is the development of a method for coordination of counsel who represent the named manufacturers in nonidentification cases.

\section{Other Legislative Considerations}

A few other problems and considerations, of a lesser degree of importance than these first four guidelines, should be mentioned here. First, any proposed legislation must address the problem of how current insurance coverage for manufacturers under the present tort hitigation system can be transferred and (in effect) captured by the new legislative system. Although this is an extremely complex problem with little precedent, the goal is clear: the legislation slould contain a provision that all insurance coverage applicable in hitigation and settlement of current DES cases should apply to manufacturers' payments of assessments or compensation claim apportionments under the legislative system. Similar provisions have been included in other types of legislation, sucl as Senate Bill 2708 in the 98th Congress, which proposed an asbestos compensation fund. ${ }^{125}$ The legislative solution would be fair to manufacturers only if it ensured that manufacturers retain the insurance coverage that they have paid for and are entitled to. Of course, the legislation should not retroactively create broader coverages for carriers beyond the contractual agreement between insurer and pohicyholder. In sum, it is essential to develop the application of present msurance coverage in legislation that facilitates the payment of claims in nonidentification cases.

Second, consideration must be given to the role and method of payment to claimant's counsel. The normal contingent fee approach may not work well in this context. To assure fair payment, but also to mimmize transaction costs, claimant's counsel should be required to keep records of their time and services, which should be reviewed before payment is made.

Third, careful consideration should be given to whether legislation

125. See S. 2708, 98th Cong., 2d Sess. (1984). 
should be state or federal. A persuasive argument can be developed that the identification cases are still in the experimental stage. The well-worn argument of Justice Brandeis that the states should be given an opportumity to act as "hittle laboratories" to address new problems is particularly persuasive here. Unlike the situation with respect to other areas of general product hability-such as standards for design and warning, or punitive damages-the identification problem is still new and solutions are in the experimental stages. Also, unlike federal product liability legislation, the legislation in this area mvolves both the creation of new mechanisms for apportionment of responsibility and, perhaps, facts and issues that are not common to product hability cases in general. The most appropriate resolution to these problems may be best left to the states. On the other hand, the products imvolved have been distributed in interstate commerce. It may be best to have one umiform method of apportioning responsibility. Fimally, it would not be desirable to encourage forum shopping by plaintiffs. In sum, two things are clear: this is a matter that deserves much more study, and it is a problem distinct from the current needs for, and development of, uniform product liability law in more traditional areas of litigation. ${ }^{126}$

Finally, there must be a determination as to whether the legislation is to be product-specific or should address the more general problem of nonidentification. As this Article has demonstrated, DES hitigation has a umique history and background. In structuring a legislative systein addressing the identification problem, this history and background must be considered. On the other hand, a wholly separate approach for nonidentification problems that have some similarities (i.e., asbestos) may be inefficient and wasteful. This is a problem that can be most efficiently explored by legislative study and examination.

There are many other issues regarding the specific provisions of a legislative solution for the identification problem: the forum for filing and hearing nonidentification claims, the mechanism for transferring payment from manufacturers to nonidentification claimants, hearings for determining apportionment of compensation in nonidentification claims, and so on. This Article has suggested the basic role and structure of a legislative solution. Development of the specific provisions for implementation of a legislative solution requires further careful study and consideration.

\section{CONCLUSION}

The case im which a person injured by a product can prove that his

126. See Schwartz \& Bares, Federal Reform of Product Liability Law: A Solution That Will Work, 13 CAP. U.L. REV. 351 (1984). 
or her injuries result from culpable conduct of the manufacturer but is unable to identify the manufacturer is a peculiar problem requiring a unique legislative solution. Courts have attempted to develop solutions in order to provide recovery to plaintiffs in litigation, but in overriding and modifying the tort system, they have created needless and extensive litigation costs. Furthermore, these judicially imposed approaches do not facilitate prompt and appropriate recoveries for injured persons and are unfair to defendants.

The general problem can be solved by legislation that would promptly provide out-of-pocket losses to injured persons. Those persons should nevertheless be required to prove all other elements of a product liability action. Such a legislative system should balance the imterests of injured persons and manufacturers. The legislature, through the hearing process, is well equipped to do this. In this Article, we have attempted to present some of the major considerations and alternatives a legislature should address if it attempts to venture down this path. While these problems are not easy to resolve, their very nature demonstrates the appropriate forum in which they ought be addressed. The legislature, if it follows these guidelines and parameters, can resolve a problem which the judicial system is not equipped or designed to handle. 